\title{
Rediscovery of the Sooty Babbler Stachyris herberti in central Vietnam
}

\author{
JONATHAN C. EAMES, FRANK R. LAMBERT and NGUYEN CU
}

\begin{abstract}
Summary
The Sooty Babbler Stachyris herberti, previously known from five specimens collected in Laos in 1920, was rediscovered in central Vietnam in July 1994. Fieldwork in Phong Nha Cultural and Historical Reserve located a population inhabiting lowland evergreen forest on limestone. The species was recorded on a number of occasions over several days and one female specimen was collected. The species appears to have highly specific ecological requirements and current human disturbance may have implications for its conservation at this site. A revision of its taxonomic position suggests its retention within the genus Stachyris.
\end{abstract}

\section{Introduction}

The Sooty Babbler or Laos Dusky Babbler Stachyris herberti was first collected by E. J. Herbert at camp no. 42, Ban Lak Sao or Ban Na Sao $\left(18^{\circ} 11^{\prime} \mathrm{N} 104^{\circ} 58^{\prime} \mathrm{E}\right)$, in Laos. The five specimens (Table 1 ) were originally and erroneously labelled as having been collected in Siam (Thailand) (Baker 1920) but this was subsequently corrected (Baker 1921, Williamson 1945). On its discovery, the Sooty Babbler was assigned to a new genus, Nigravis, and named in honour of the collector by E. C. S. Baker (Baker 1920, 1921). There was no subsequent observation of the species for 74 years and it was listed as Vulnerable in a recent review of globally threatened birds (Collar et al. 1994), where its rediscovery was mentioned.

\section{The rediscovery}

During June and July 1994 we undertook ornithological surveys at a number of sites, including protected areas in the Annamese Lowlands Endemic Bird Area (EBA) - see ICBP (1992) - in central Vietnam, as part of the ongoing BirdLife International Vietnam Programme. The aim of this survey was to identify and evaluate sites for the establishment of protected areas in the Annamese Lowlands EBA. Phong Nha Cultural and Historical Site (Quang Binh province), $17^{\circ} 25^{\prime} \mathrm{N} 106^{\circ} 15^{\prime} \mathrm{E}$, encompassing $400 \mathrm{~km}^{2}$ of lowland evergreen forest, much of it on limestone, was selected as a survey site because of its proximity to Dong Hoi, the locality from which Imperial Pheasant Lophura imperialis was first obtained. Thus, the primary objective at this site was to determine whether forest there supported a population of this enigmatic species of pheasant (see 


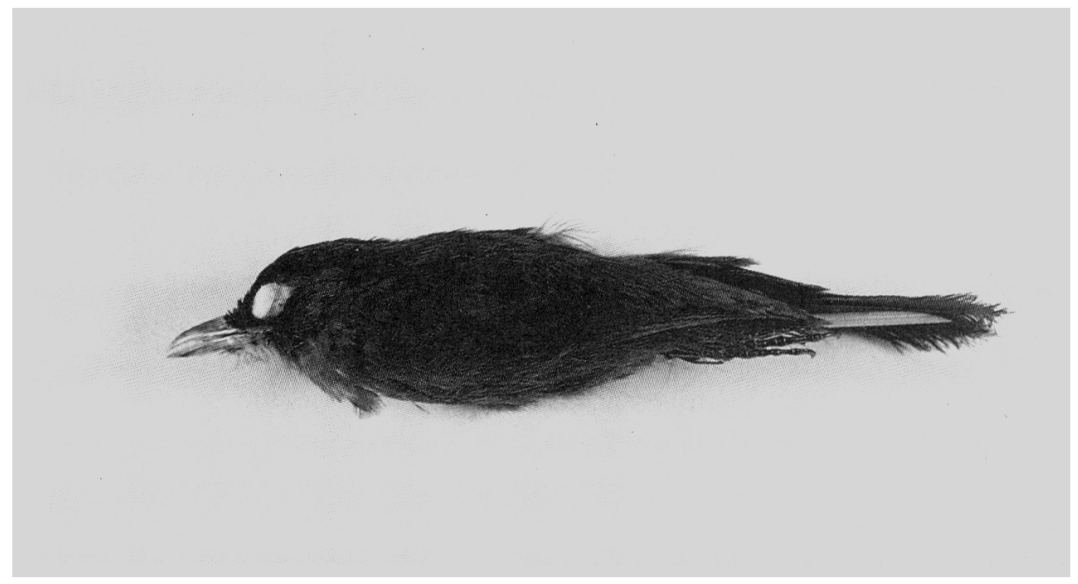

Figure 1. Specimen of Sooty Babbler Stachyris herberti collected at Phong Nha, July 1994 (photograph by J. C. Eames).

Eames et al. 1994). However, we were certainly aware of the possibility that $S$. herberti could occur in the area.

On 7 July whilst conducting a survey in a narrow-bottomed forested limestone gorge, we observed several flocks of $S$. herberti. The birds were confiding, which permitted close observation down to three to four metres, and the species was recorded daily at the same locality until 11 July. Attempts were made to mist-net the birds using playback of their calls, to determine whether the population could represent an undescribed subspecies. Such attempts were unsuccessful and on 11 July a single individual was collected. The specimen is now held in the bird collection of the Institute for Ecology and Biological Resources in Hanoi (Figure 1).

\section{Description}

In the field, the adults appeared uniformly dark sooty-brown with a purplebronze sheen and a clearly demarcated white throat. The adults showed a bluegrey eye-ring which appeared to be reduced or absent in some individuals, presumed to be juveniles. In the hand the plumage of the female specimen obtained at Phong Nha was noted in detail.

Forehead, lores, crown, nape, mantle, scapulars, wing-coverts, rump and upper tail-coverts were rich sooty-brown with a warm purple tinge. The feathers of back and rump appeared soft, long, loose and slightly fluffy. The ear-coverts were paler with a pinkish hue. The tips of the feathers on the chin and throat were sooty-brown but the base of the feathers was white, making the chin and throat appear whitish. The breast and belly were sooty-brown but lighter and greyer than the upperparts. The flanks were darker sooty-brown, more similar to the upperparts. Atypically, the specimen had a number of white contour feathers on the lower left flank. The tertials, secondaries and primaries were dark brown. The tail was darker brown than the primaries and secondaries, with indistinct bands, rather like growth-bars. 
Table 1. Biometrics of Stachyris herberti specimens at the Natural History Museum (Tring, U.K.) and Institute for Ecology and Biological Resources (Hanoi)

\begin{tabular}{lllllll}
\hline Specimen number & Date & Sex & Tarsus & Bill & Wing & Tail \\
\hline 16033 & $24 / 02 / 20$ & Male & 24 & 19 & 72 & 78 \\
16034 & $24 / 02 / 20$ & Male & 27 & 22 & 74 & 80 \\
16035 & $24 / 02 / 20$ & Female & $25 \cdot 5$ & 19 & 72 & 70 \\
16036 & $24 / 02 / 20$ & Female & 25 & 19 & 72 & 70 \\
192010241 holotype & $24 / 02 / 20$ & Male & 25 & 19 & 76 & 80 \\
& & & $\left(28^{\mathrm{a}}\right)$ & $(18)$ & $(78)$ & $(72)$ \\
$\mathrm{BT}_{2744}$ & $11 / 07 / 94$ & Female & 23 & 19 & 74 & 66 \\
\hline
\end{tabular}

a Measurements of holotype given in Baker (1920).

The iris was dark brown and the orbital ring was pale bluish-grey; the legs were blackish-horn with yellowish-buff soles, and the claws were blackish-horn. The middle toe (including claw) measured $21 \mathrm{~mm}$ and the hind claw $8 \mathrm{~mm}$; other measurements are given in Table 1 . The fresh weight of the bird was $29 \mathrm{~g}$. The abdominal cavity contained three live nematodes. In addition, there was a small cyst located on the interior abdominal wall of the epidermis.

\section{Behaviour and voice}

Sooty Babblers were observed in flocks of $4-25$ birds but usually in single-species groups of 4-10. Only twice were they seen in the company of a mixed-species flock which contained Streaked Wren-babbler Napothera brevicaudata, Greythroated Babbler Stachyris nigriceps, Striped Tit-babbler Macronous gularis, Sulphur-breasted Warbler Phylloscopus ricketti, Common Tailorbird Orthotomus sutorius and Black-naped Monarch Hypothymis azurea.

$S$. herberti foraged on the limestone and associated woody vegetation, especially amongst vines and lianas. Birds frequently climbed vertically up and down the rock-face, sometimes disappearing into holes which honeycombed the limestone. They were entirely arboreal except when on the rocks, and were never once seen to forage on or across the forest floor, but were seen near the ground. They were able to run rapidly along vines and creepers. The birds held their bodies in a horizontal position and kept their tails slightly fanned at all times. The approach of a flock of $S$. herberti was heralded by the call, a subdued metallic "cheet cheet cheet" which was given continuously by members of the flock whilst foraging (Figure 2). Birds were observed feeding on a harvestman (Opiliones), a caterpillar (Lepidoptera) and possibly a bug (Hemiptera).

\section{Habitat}

The birds located at Phong Nha were observed only on limestone outcrops and amongst vines, lianas and undergrowth within closed-canopy lowland evergreen forest in a narrow limestone gorge at 50-100 $\mathrm{m}$ altitude.

\section{Discussion}

Although Baker (1920) assigned the Sooty Babbler to the monotypic genus Nigravis it was subsequently included in Stachyris by Peters (1964) and King et al. 


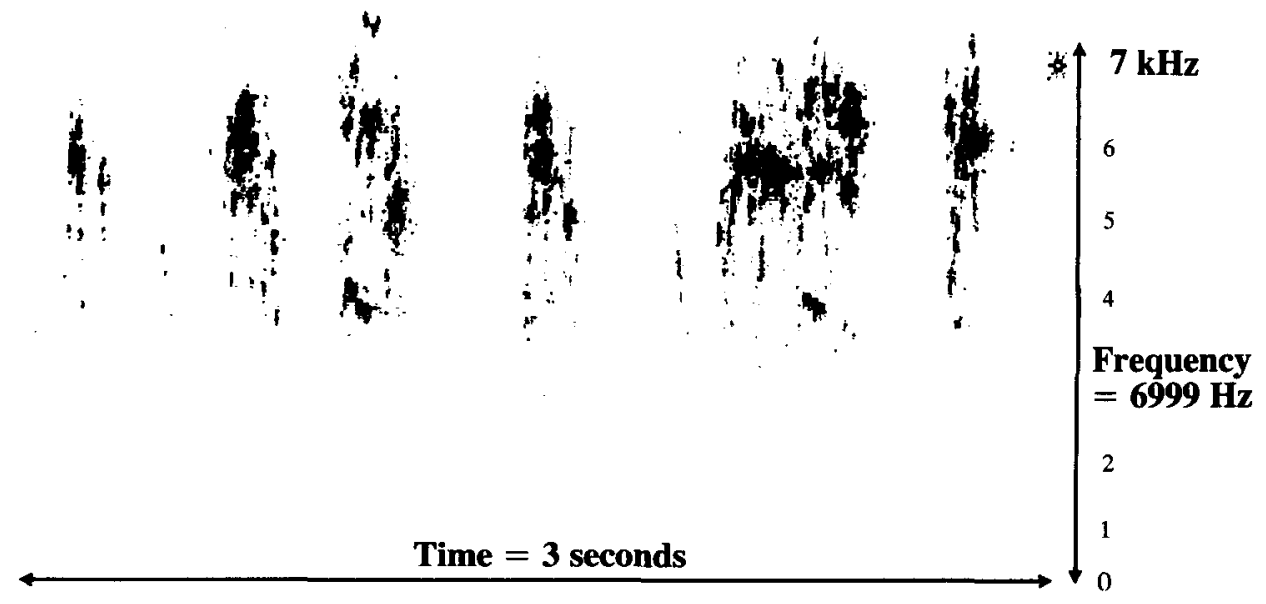

Figure 2. Sonagram of call of Sooty Babbler Stachyris herberti, July 1994.

(1975). On his justification for describing a new genus, Baker wrote "This bird undoubtedly belongs to the Timeliidae (sic), or Turdoidae as they must now be called, but I know of no genus within that family with which it can be placed. The wing is typically rounded, the first feather being about half the length of the sixth and the sixth to the tenth are subequal and longest, whilst the outermost secondary is only $2 \mathrm{~mm}$ shorter. The tail-feathers are broad and graduated and the tarsus fairly stout but not very long; the bill is like that of Aethsotma (Turdinus), but the nostril is completely covered by an operculum, and the feathers on either side of the base of the bill grow right up to the posterior edge of the nostril. There are three very short rectil bristles and the feathers of the chin have fine hair-like tips" (Baker 1920). This diagnosis was later defended and reiterated (Baker 1921).

The genus Stachyris was first and somewhat imprecisely defined thus: "Beak moderately slender, straight, compressed, and tapering sharp to the extremity, where the tip of the upper mandible has a very slight downward inclination, with little or no trace of a notch; nostrils almost closed by an impending scale; and rictus nearly smooth. Tarse (sic) of mean length and straight, the outer and inner front toes subequal; and claws moderate. Wings rounded, the 5th, 6th, and 7 th primaries equal and longest: exterior three or four pairs of tail-feathers graduated. Crown subcrested, the feathers of this part semi-erect and more or less divergent" (Hodgson 1844).

Many of these features are shared by several genera of passerines including babblers. The presence of an operculum closing the nostril is the most characteristic morphological feature of Stachyris (Greek stakhus = ear of wheat, rhis = nose: Jobling 1991), and this is indeed shown by $S$. herberti. There is no feature, or combination of features, described by Baker that sufficiently justifies the description of a new genus, and we thus find his case wanting on morphological grounds. Furthermore, $S$. herbert $i$ is gregarious, associates with other passerines, and inhabits the shrub layer, all features shown by other members of the genus and, indeed, the family. The call, however, is a little unusual for a Stachyris babbler and does not appear to contain any "hu" or "pup" notes, although the song remains undescribed. Moreover, the stance, with tail fanned, is somewhat 
atypical for a Stachyris babbler, and the birds' slow and purposeful movements through the undergrowth are also not particularly reminiscent of the genus. On balance, however, the morphological evidence suggests Stachyris and thus we opt to retain the species in this genus, rather than reinstate Nigravis.

From a comparison of the measurements given in Table 1 the bill and wing length of the Vietnamese specimen fall within the range given for the holotype and topotypes, but the measurement of tarsus and tail fall just outside the range. The plumage coloration of all specimens was similar, but those from Laos were browner in general and warmer brown on the mantle where the Vietnamese specimen was slightly greyer - though this difference may have been due to foxing in the older specimens. There were no differences in the colour of the underparts or the remiges and rectrices.

The iris in the five specimens obtained in Laos was brown, for four specimens from Laos the bill was described as blue and bluish-white in the holotype, and the legs of four of the specimens from Laos were brown and blackish-brown in the holotype. This is very similar to the bare-part coloration of the Vietnamese specimen.

On the limited evidence available, we believe there is insufficient evidence to describe a new taxon and therefore suggest that $S$. herberti is monotypic.

Although no mention of habitat is made in Baker (1920, 1921) or Williamson (1945), and while Delacour and Jabouille (1931) state that nothing is known of the ways of this very rare and unusual bird, it was suggested by King et al. (1975) that $S$. herberti might occur in limestone outcrops. Our observations confirm this suspicion.

Although S. herberti was amongst the commonest passerines at Phong Nha, it was not possible to make a quantitative assessment of population size in the time available. Local people have cleared forest from valley bottoms between the karst outcrops, and trees were being cut for timber, so the species may be threatened at this site. Recent attempts to locate the species near the typelocality in Laos have been unsuccessful (R. J. Timmins in litt. 1994), so we suggest retaining its current conservation category of threat.

The rediscovery of $S$. herberti is significant for four reasons: the species had not been recorded for more than 74 years; its rediscovery in Vietnam adds a second range state to its known distribution; its rediscovery in the Annamese Lowlands increases the number of restricted-range species known in the EBA from eight to nine species (ICBP 1992); and the rediscovery occurred in a protected area, thus elevating Phong Nha Cultural and Historical Site to a protected area of international importance. The discovery there of a population of the little-known and endemic François's leaf-monkey Semnopithecus (francoisi) hatinhensis adds further to the international importance of the site.

Given these factors we suggest that Phong Nha Cultural and Historical Site be re-designated a nature reserve and that the allocation of financial resources for the development of the protected area be made a priority (see also Eames et al. 1994); and that urgent measures be taken to protect forest in Phong Nha, particularly in valley bottoms between areas of karst at the locality. It is also recommended that further surveys at Phong Nha be undertaken to assess habitat requirements, total estimated population size, and the scale and nature of any threats to either Sooty Babbler or François's leaf-monkey. 


\section{Acknowledgements}

We would like to extend our thanks to the following individuals and institutions for providing help and assistance to us in our work. In Hanoi, at the Ministry of Forestry we owe particular thanks to Mr Nguyen Mau Tai, Director of the Forest Protection Department, Mr Bui Xuan Yen, Director of the International Cooperation Department, Mr Tran Dinh Dan, Vice-Director of the Forest Protection Department, Dr Nguyen Nhu Phuong, Chief, Management of National Forest Parks, Nature Reserves and Wildlife, Mr Pham Mong Giao, Senior Expert of Biology, Dr Nguyen Huu Dong, Director of Forest Resources and Environment Centre of FIPI, and Dr Nguyen Manh Cuong, Head of Remote Sensing Section of the Forest Resources and Environment Centre, Forest Inventory and Planning Institute. Thanks also go to Professor Dr Dang Huy Huynh, Director of the Institute of Ecology and Biological Resources, Hanoi, for permitting the secondment of Dr Nguyen Cu to the project. In Quang Binh province we thank $\mathrm{Mr}$ Bui Ngoc Tu, Vice-Chairman of the Provincial Forest Protection Department, Mr Nguyen Van Huyen, Vice-Chairman of Phong Nha Cultural and Historical Site, and his staff, Mr Hoang Que, and the people of Truong Son village, Son Trach, Bo Trach District. In the U.K. we would like to thank Richard Ranft and the British Library of Wildlife Sounds for producing a sonagram and the Natural History Museum (Tring) for granting access to bird specimens. This fieldwork comprised part of the BirdLife International Project entitled "Conservation of Biodiversity in the Annamese Lowlands and the Da Lat Plateau, Vietnam" Con-

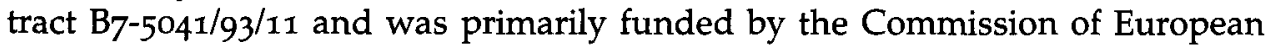
Communities (DG1). Additional funding was made available by the Species Survival Commission of IUCN (The World Conservation Union) through a grant from the National Wildlife Federation (U.S.A.).

\section{References}

Baker, E. C. S. (1920) [Description of new genera, species and subspecies from a collection of birds by Mr E. G. Herbert in Siam.] Bull. Brit. Orn Club 41: 10-11.

Baker, E. C. S. (1921) [Diagnosis of the genus Nigravis.] Bull. Brit. Orn Club 41: 101.

Collar, N. J., Crosby, M. J., and Stattersfield, A. J. (1994) Birds to watch 2: the world list of threatened birds. Cambridge, U.K.: Birdlife International (Birdlife Conservation Series no. 4).

Delacour, J. and Jabouille, P. (1931) Les oiseaux de l'Indochine française, 3. Paris: Exposition Coloniale Internationale.

Eames, J. C., Lambert, F. R. and Nguyen Cu (1994) A survey of the Annamese Lowlands, Vietnam, and its implications for the conservation of Vietnamese and Imperial Pheasants Lophura hatinhensis and L. imperialis. Bird Conserv. Internatn. 4: 343-382.

Hodgson, B (1844) [Diagnosis of the genus Stachyris.] J. Asiatic Soc. 149: 378.

ICBP (1992) Putting biodiversity on the map: priority areas for global conservation. Cambridge, U.K.: International Council of Bird Preservation.

Jobling, J. A. (1991) A dictionary of scientific bird names. Oxford, U.K.: Oxford University Press.

King, B. F., Dickinson, E. C. and Woodcock, M. W. (1975) A field guide to the birds of South-East Asia. London: Collins. 
Peters, J. L. (1964) Check-list of the birds of the world, 10. Cambridge, Mass.: Harvard University Press/Museum of Comparative Zoology.

Williamson, W. (1945) On some birds from Thailand, etc. Ibis 87: 52-69.

JONATHAN C. EAMES

BirdLife International Vietnam Programme, 12 Cao Ba Quat, Ba Dinh, Hanoi, Vietnam.

FRANK R. LAMBERT

Species Survival Commission, IUCN, $219 c$ Huntingdon Road, Cambridge CB3 oDL, U.K.

NGUYEN CU

BirdLife International Vietnam Programme, 12 Cao Ba Quat, Ba Dinh, Hanoi, Vietnam. 